\title{
Parameters of lung inflammation in asthmatic as compared to healthy children in a contaminated city
}

Benigno Linares Segovia ${ }^{1,2,6^{*}}$, Gabriela Cortés Sandoval ${ }^{1}$, Norma Amador Licona ${ }^{3}$, Juan Manuel Guízar Mendoza ${ }^{4}$, Estela Núñez Lemus ${ }^{1}$, Diana Olivia Rocha Amador ${ }^{5}$, Xóchitl Sofía Ramírez Gómez ${ }^{1}$ and Rebeca Monroy Torres ${ }^{1}$

\begin{abstract}
Background: The impact of air pollution on the respiratory system has been estimated on the basis of respiratory symptoms and lung function. However; few studies have compared lung inflammation in healthy and asthmatics children exposed to high levels of air pollution. The aim of the study was to elucidate the modulatory effect of air pollution on Cysteinyl-leukotrienes (Cys-LTs) levels in exhaled breath condensate (EBC) among healthy and asthmatic children.

Methods: We performed a cross-sectional comparative study. Children between 7-12 years of age, asthmatics and non-asthmatics, residents of a city with high levels of PM 10 were included. In all cases, forced spirometry, Cys-LTs levels in EBC, and the International Study of Asthma and Allergies in Childhood questionnaire were evaluated. We also obtained average of $\mathrm{PM}_{10}, \mathrm{CO}, \mathrm{SO}_{2}$ and $\mathrm{O}_{3}$ levels during the period of the study by the State Institute of Ecology.

Results: We studied 103 children (51 asthmatics and 52 non-asthmatics). Cys-LTs levels were higher in asthmatics than in non-asthmatics (77.3 \pm 21.6 versus $60.3 \pm 26.8 \mathrm{pg} / \mathrm{ml} ; \mathrm{p}=0.0005)$. Also, Cys-LTs levels in children with intermittent asthma were lower than in children with persistent asthma $(60.4 \pm 20.4$ versus $84.7 \pm 19.2 \mathrm{pg} / \mathrm{ml}$; $p=0.0001)$. In the multiple regression model, factors associated with levels of Cys-LTs were passive smoking ( $\beta=13.1, \mathrm{p} 0.04)$ and to be asthmatic $(\beta=11.5, \mathrm{p} 0.03)$.
\end{abstract}

Conclusions: Cys-LTs levels are higher in asthmatic children than in healthy children in a contaminated city and its levels are also associated with passive smoking.

Keywords: Air pollution, Lung inflammation, Cysteinyl-leukotrienes, Exhaled breath condensate

\section{Background}

Air pollution has become a global public health problem. It is considered by the World Health Organization (WHO) as a global health priority, according to a recent study, the air pollution is responsible for $1.4 \%$ of all deaths in the world [1].

Epidemiological studies show that exposure to air pollution, is associated with an increased incidence and severity of asthma [2,3], acute respiratory infections $[4,5]$,

\footnotetext{
* Correspondence: blinares70@yahoo.com.mx

'Department of Medicine and Nutrition, Division of Health Sciences,

University of Guanajuato, León, Guanajuato, México

2Department of Teaching and Research PEMEX Regional Hospital Salamanca, Salamanca, Guanajuato, México

Full list of author information is available at the end of the article
}

pulmonary function decline [6] and other chronic obstructive pulmonary disease $[7,8]$.

Most of literature has taken as health indicators, hospital admissions or attendance at the emergency services. However, not all people are exposed to this impact on health in the same conditions; the most vulnerable groups are children and elderly people. The child population has certain characteristics that make them more susceptible to environmental impact unlike adults. Thus, from the point of view of the dose compared with adults, children breathe faster and play outdoors often, therefore, due to its lower weight is greater exposure per unit mass. On the other hand, due to its constant state of development and growth, physiologically immune system and organs are 
still immature, also irritation and inflammation caused by contaminants easily obstructs their airways [9].

The contaminants frequently associated with asthma exacerbations are: carbon monoxide, ozone, nitrogen dioxide, sulfur dioxide and particulate matter with a diameter of 10 micrometers or less $\left(\mathrm{PM}_{10}\right)$. Continuous exposure to low doses of allergens in patients sensitized causes increased bronchial hyperreactivity, decreased steroid receptor affinity, and therefore, increases the susceptibility to asthma attacks and reduces the response to treatment steroids $[3,10]$.

There are two proposed mechanisms for respiratory disease due to exposure to air pollutants. The first involves a reduction in the forced vital capacity, through to the stimulation of neural receptors in the upper airway due to the release of cyclooxygenase, products of the arachidonic acid [11]. The other mechanism has been linked to the recruitment of inflammatory cells and in general to the inflammation process [12-14].

The impact of air pollution on the respiratory system has been estimated in terms of respiratory symptoms, lung function and other outcomes. However, there are few reports worldwide about the involvement of cysteinylleukotrienes (Cys-LTs) in the pathogenesis of lung inflammation $[15,16]$. The aim of this study was to elucidate the modulatory effect of air pollution on Cysteinyl-leukotrienes (Cys-LTs) levels in exhaled breath condensate (EBC) among healthy and asthmatic children.

\section{Methods}

\section{Study population}

We performed a cross-sectional comparative study. As inflammation biomarker Cisteinyl-leukotrienes in exhaled breath condensate (EBC) was measured. A sample size of 37 subjects per group was calculated (asthmatic and nonasthmatic) using the statistic $t$, according to detect a difference of at least $10 \%$ in the levels of Cys-LTs with an alpha of 0.05 , unilateral beta 0.10 and a power of 0.90 . Increased $20 \%$ for losses $(n=90)$. We included children 7-12 years of age, asthmatics and non-asthmatics, residents of a city with high levels of $\mathrm{PM}_{10}$.

The study took place in the urban area of León, Mexico from September, 2010 to March, 2011. The municipality has a territorial extension of $1200 \mathrm{~km}^{2}$ (3.9\% of the total state surface), a population of 1.5 million inhabitants and a population density of 1,250 inhabitants per $\mathrm{km}^{2}$. Its climate is temperate most of the time, and it forms part of the industrial corridor of the state. According to reports of the National Institute of Ecology [17], it is one of the cities with high air pollution by $\mathrm{PM}_{10}$ (average of $64.5 \mathrm{\mu g} / \mathrm{m}^{3}$ with a range of $41.2-82.6 \mathrm{ug} / \mathrm{m}^{3}$ ). The main producers of this pollutant are sources of area and emissions from motor vehicles.
We studied healthy or asthmatics children who were able to cooperate with the test. Children who had wheeze due to concomitant nonasthmatic chronic airway diseases like cystic fibrosis or patients with asthma who had suffered an exacerbation within a month of the study period were excluded from the study. Children with asthma were recruited from the Pediatric Outpatients Clinics of Regional General Hospital of Leon, Mexico. Normal age-matched control subjects were recruited from a public elementary school located in the same city $2 \mathrm{~km}$ away from the monitoring station. None of the participants had been treated with leukotriene inhibitors. Permission was obtained from the authorities of the State Department of Education and from the participating school. The parents, as well as each of the participants, were informed about the objective of the study and the procedures before obtaining consent to participate. The study was approved by the Research Committee of the Department of Medicine and Nutrition of the University of Guanajuato, and was authorized with the registration number $358-10$.

\section{Study design}

A detailed history was taken and physical examination performed on each child. Weight and height were recorded to calculate the body mass index (BMI). Asthma was diagnosed when the child had episodic cough, breathlessness, and wheeze responsive to bronchodilators with or without steroids. The medical and sociodemographic history were obtained through the questionnaire proposed by the International Study of Asthma and Allergies in Childhood (ISAAC) validated in a previous study [6].

Lung function was measured by forced spirometry. The spirometry was performed with a spirometer EasyOne ${ }^{\circ}$ (NDD, Technopark darned Switerland), which meets the diagnostic criteria for precision, accuracy and linearity, established by the American Thoracic Society (ATS, 1994). To carry out follow the recommendations of the ATS and the following parameters were obtained: Forced Vital Capacity (FVC), Forced Expiratory Volume in one second $\left(\mathrm{FEV}_{1}\right)$ and $\mathrm{FVC} / \mathrm{FEV}_{1}$ ratio. The presence of spirometric values below the fifth percentile was considered abnormal according to height, weight, gender and age.

The quality of spirometric tests was assessed by several criteria in addition to the automatic evaluation done by the software device. One was the number of acceptable maneuvers according to ATS, 1 ranging from 0 to 3, the highest kept by the spirometric software. Another indicator of quality was reproducibility. FEV 1 and FVC were considered reproducible according to ATS criteria when the best two trials differed by not more than $200 \mathrm{~mL}$. A total of $97.5 \%$ of the tests achieved reproducibility within $150 \mathrm{~mL}$ fulfilling the 2005 ATS-ERS criteria. Reference values of Hankinson et al. [18] for Mexican-Americans 
were used, considering that children $>7$ years old can fulfill ATS criteria of quality after the first spirometric evaluation. The presence of spirometric values below the $5^{\text {th }}$ percentile of reference values were considered abnormal. The obstructive pattern was defined by the diminution of the $\mathrm{FEV}_{1}$ and $\mathrm{FEV}_{1} / \mathrm{FVC}$ index, the restrictive pattern by diminution of the $\mathrm{FVC}$, with normal $\mathrm{FEV}_{1} / \mathrm{FVC}$ index, and mixed pattern by diminution of FVC and $\mathrm{FEV}_{1}$.

\section{Exhaled breath condensate analysis}

Exhaled breath condensate collection was performed using the RTube $^{\text {TM }}$ EBC collection system (Respiratory Research, Inc, Charlottesville, Virginia, USA). Subjects breathed tidally for 15 minutes, nose clips were not worn, because they are somewhat uncomfortable. The condensate samples were obtained at an average ambient temperature of $13^{\circ} \mathrm{C}$. The mean volume collected was 1.2 (range $0.7-1.1 .8) \mathrm{ml}$. The collected condensate was melted and aliquots of $100 \mu \mathrm{L}$ stored in small plastic tubes at $-80^{\circ} \mathrm{C}$.

\section{Biochemical assays}

Cys-LTs (LTC4, LTD4, and LTE4) levels were measured with a specific enzyme immunoassay (Cayman Chemical, Ann Arbor, MI), at a wavelength of $410 \mathrm{~nm}$. The lower limit of detection for these assays was $4 \mathrm{pg} / \mathrm{ml}$. The intra-and interassay coefficients of variation of the kits were $10 \%$ or less and every sample was assayed by duplicate.

\section{Data analysis}

All data are expressed as means \pm SEM or as median and 95\% CI according to their normal distribution. Comparison of demographic and clinical data was performed using chi square or Student's t test according to the type of variable. Comparison of demographic data was done by a chi-square test. To compare the concentration of exhaled Cys considered three groups: non-asthmatics, intermittent asthma and persistent asthma and use analysis of variance with post hoc Tukey test. We used the Pearson correlation test to determine the association between levels of cysteinylleukotrienes and spirometric values. Stepwise multiple regression was performed with cysteinyl-leukotriene levels as the dependent variable and group, age, gender, body mass index, the antecedent atopy, exposure to allergens and passive smoking as regressors. Air pollutants were captured as mean values of all the period of the study.

\section{Results}

\section{Clinical characteristics}

One hundred three subjects were enrolled into the study, with a mean age of $9.0 \pm 1.3$ years. We observed no significant difference in gender distribution between groups. Asthmatics children were older and showed higher BMI than those non-asthmatics. In contrast, they showed lower FEV1 and FEV1/FVC\% than healthy children (Table 1).

\section{Allergic diseases and respiratory symptoms}

According to the ISAAC questionnaire, the frequency of respiratory symptoms (cough, wheezing, and rhinorrhea) and allergic (rhinitis and eczema) diseases was significantly higher in asthmatic children (Table 2).

\section{Pulmonary function}

The spirometry data showed that forced vital capacity in asthmatic children was higher than in non-asthmatics, although this difference was not significant. No significant differences were observed in absolute FEV1. In contrast, the percentage of predicted FEV1 in non-asthmatic children was significantly higher than in asthmatics ( $\mathrm{p}=$ 0.003). According to spirometric values, lung function abnormalities were higher in the asthmatic group than in non-asthmatics. Also, impaired lung function "obstructive-type", was more common in asthmatics, but we did not observe significant difference in "restrictive-type" or "mixed-type" disorders between groups (Table 2).

\section{Air pollutants}

According to reports of the State Institute of Ecology, average $\mathrm{PM}_{10}$ levels during the period were $196.7 \mu \mathrm{g} / \mathrm{m}^{3}$ with a range of $64.1-217.9 \mu \mathrm{g} / \mathrm{m}^{3}$ which represents 176 days of measurement. The corresponding averages for other pollutants were: $\mathrm{O}_{3}=26.32 \mu \mathrm{g} / \mathrm{m}^{3}$ (15.8-30.9), $\mathrm{SO}_{2}=7.8 \mu \mathrm{g} / \mathrm{m}^{3}$ (5.0-11.6), $\mathrm{CO}=0.96 \mathrm{ppm}(0.57-1.68)$, and $\mathrm{NO}_{2}=\mu \mathrm{g} / \mathrm{m}^{3} 19.6(14.6-26.8)$ in the same period of time.

\section{Exhaled Cys-LTs}

The Cys-LTs levels were detected in the EBC of all children, with mean of $68.7 \pm 25.7 \mathrm{pg} / \mathrm{ml}$. The Cys-LTs levels were significantly higher in asthmatics than in non-asthmatics $(77.3 \pm 21.6$ versus $60.3 \pm 26.8 \mathrm{pg} / \mathrm{ml} ; \mathrm{p}=0.0005)$. The average concentration of exhaled Cys-LTs in children with

Table 1 Clinical characteristics of the study populations

\begin{tabular}{lccc}
\hline Group & $\begin{array}{c}\text { Asthmatic } \\
\mathbf{n}=\mathbf{5 1}\end{array}$ & $\begin{array}{c}\text { No asthmatic } \\
\mathbf{n = 5 2}\end{array}$ & $\mathbf{P}$ \\
\hline Gender (male/female) & $30 / 22$ & $27 / 25$ & 0.55 \\
Age (years) & $9.5 \pm 1.5$ & $8.5 \pm 0.9$ & 0.0004 \\
Weight (kg) & $36.7 \pm 6.0$ & $31.8 \pm 6.8$ & 0.004 \\
BMl (kg/m ${ }^{2}$ ) & $18.9 \pm 4.2$ & $17.3 \pm 2.7$ & 0.02 \\
FVC (liters) & $2.2 \pm 0.6$ & $2.0 \pm 0.3$ & 0.06 \\
FVC (\% predicted) & $97.8 \pm 15.3$ & $98.2 \pm 24.1$ & 0.91 \\
FEV1 (liters) & $1.7 \pm 0.5$ & $1.6 \pm 0.2$ & 0.30 \\
FEV1 (\% predicted) & $86.0 \pm 14.7$ & $93.6 \pm 10.8$ & 0.003 \\
FEV1/FVC\% & $78.3 \pm 8.3$ & $82.9 \pm 9.2$ & 0.01 \\
\hline
\end{tabular}


Table 2 Prevalence of respiratory symptoms, allergic diseases and lung function disorders

\begin{tabular}{|c|c|c|c|c|}
\hline & $\begin{array}{c}\text { Asthmatic } n=51 \\
\text { No. (\%) }\end{array}$ & $\begin{array}{c}\text { Non-asthmatic } \mathrm{n}=52 \\
\text { No. (\%) }\end{array}$ & $\begin{array}{c}\text { OR } \\
(95 \% \mathrm{Cl})\end{array}$ & $p$ value \\
\hline \multicolumn{5}{|l|}{ Respiratory symptoms: } \\
\hline Cough & $47(92.1)$ & $13(25.0)$ & $3.6(2.2-5.9)$ & 0.0001 \\
\hline Wheezing & $50(98.0)$ & $5(9.6)$ & $10.2(4.4-23.4)$ & 0.0001 \\
\hline Rhinorrhea & $51(100)$ & $44(84.6)$ & $1.1(1.05-1.3)$ & 0.003 \\
\hline \multicolumn{5}{|l|}{ Allergic diseases: } \\
\hline Rhinitis & $24(47.0)$ & $3(5.7)$ & $8.1(2.6-25.4)$ & 0.0001 \\
\hline Eczema & $15(29.4)$ & $1(1.9)$ & $15.2(2.1-111.5)$ & 0.0001 \\
\hline Type of impaired lung function: & $16(31.4)$ & $6(11.4)$ & $2.7(1.1-6.3)$ & 0.02 \\
\hline Obstructive & $10(19.6)$ & $2(3.8)$ & $5.2(1.2-22.5)$ & 0.01 \\
\hline Restrictive & $1(1.9)$ & $2(3.8)$ & $0.65(0.06-6.9)$ & 0.56 \\
\hline Mixed & $5(9.8)$ & $2(3.8)$ & $2.9(0.5-12.5)$ & 0.22 \\
\hline
\end{tabular}

intermittent asthma was significantly lower than in children with persistent asthma $(66.4 \pm 20.4$ versus $84.7 \pm$ $19.2 \mathrm{pg} / \mathrm{ml} ; \mathrm{p}=0.02)$. The analysis of variance with post hoc Tukey test showed that Cys-LTs levels in children with persistent asthma were significantly higher than in those with intermittent asthma $(\mathrm{p}=0.02)$ and nonasthmatics $(\mathrm{p}=0.001)$ Figure 1 .

There was no correlation between Cys-LTs levels and spirometric parameters (FVC, FEV1, FEV1/FVC\%). In the multiple regression model, factors associated with levels of
Cys-LTs were passive smoking $(\beta=13.1, \mathrm{p} 0.04)$ and to be asthmatic $(\beta=11.5$, p 0.03).

\section{Discussion}

It is well documented that high levels of many airborne pollutants can adversely affect many systems of the human body. Epidemiological studies have shown that exposure to air pollutants, even at levels below the standard, are associated with an increased incidence and

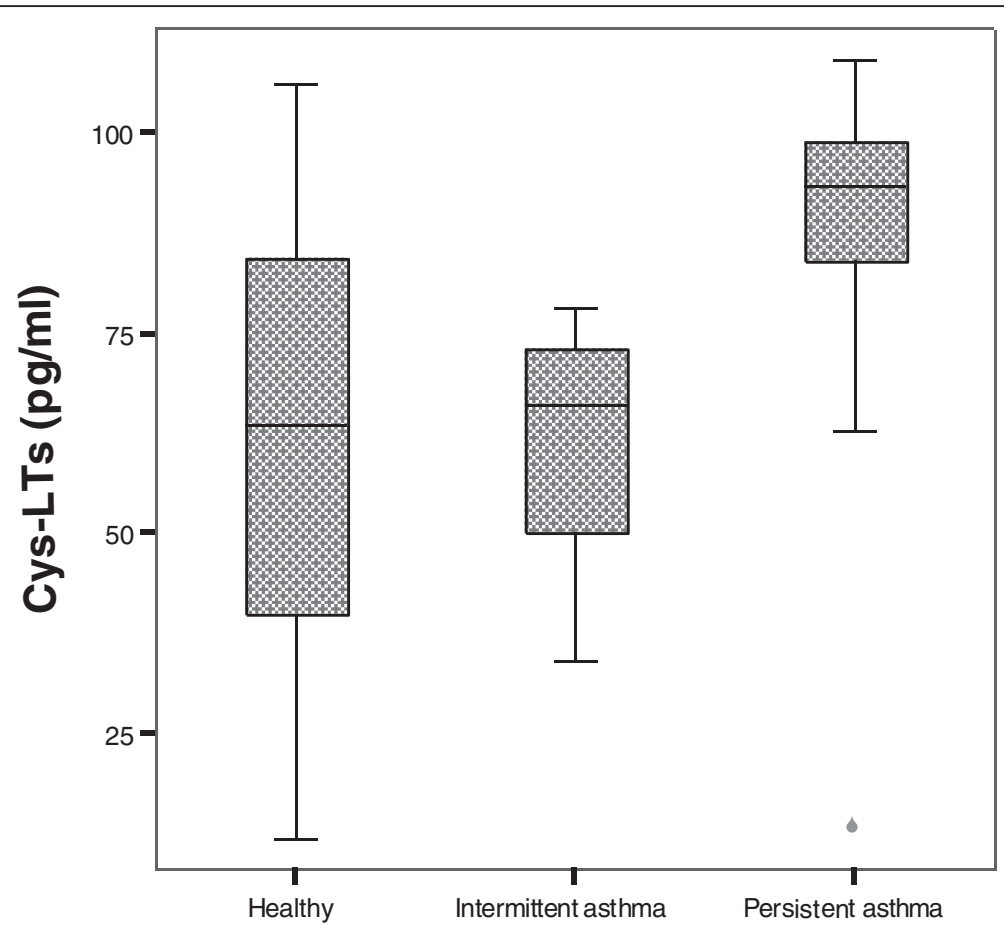

Figure 1 Cys-LTs levels in exhaled breath in healthy children and those with asthma. Cys-LTs levels in children with persistent asthma $(84.7 \pm 19.2 \mathrm{pg} / \mathrm{ml})$ were significantly higher than in those with intermittent asthma $(66.4 \pm 20.4 \mathrm{pg} / \mathrm{ml} ; \mathrm{p}=0.02)$ and non-asthmatics $(60.4 \pm 20.4 \mathrm{pg} / \mathrm{ml}$; $p=0.001)$. 
severity of asthma with pulmonary function decline as well as chronic obstructive pulmonary disease exacerbation.

To know the adverse effects of air pollution on human health, time series ecological studies have been used. In our country there are two multicenter studies conducted in 16 cities, which analyze the effects of air pollutants on mortality (EMECAM) and morbidity (EMECAS project). These works show a significant association between air pollutants and health indicators.

In this study, the prevalence of respiratory symptoms (cough, wheezing, and rhinorrhea) and allergic diseases (rhinitis and eczema) were significantly higher in children with asthma than in healthy children, as well as the prevalence of impaired lung function measured by spirometry. These results are consistent with the well known facts that asthmatic children have more respiratory symptoms, lower lung function, and evidence of airway inflammation compared to non-asthmatic children [4-6] which also increase in places with high air pollution.

The Cys-LTs levels in exhaled breath condensate were higher in children with asthma than in non-asthmatics. These findings agree with those reported by Csoma $\mathrm{Z}$ et al. [19] and by Baraldi et al. [20], in healthy and asthmatic schoolchildren 4-16 years old. Also Cys-LTs levels were higher in persistent than in intermittent asthma, these results support that Cys-LTs play an important role in the mechanism of lung inflammation. For example it has been described that they participate in the pathophysiology of airway remodelling [21] and in the pathophysiology of asthma [22]. In vitro studies have shown that $\mathrm{LTD}_{4}$ augments epidermal growth factorinduced human airway smooth muscle proliferation [23] and that $\mathrm{LTC}_{4}$ up regulates collagenase expression and synthesis in human lung fibroblasts [24]. Furthermore, animal models have shown that an increase in airway smooth muscle cells observed in allergen-treated Brown Norway rats was reduced by $\mathrm{CysLT}_{1}$ receptor antagonism [25]. So, it seems that current asthma treatment mainly based on disease severity classification has to change more focused on the individual patient [26].

As a relevant observation, Cys-LTs levels in EBC were higher in our study than in others $[19,20,27]$. Even healthy children showed higher levels $(60.3 \mathrm{pg} / \mathrm{mL})$ than those reported by Czoma et al. [19] $(18.5 \mathrm{pg} / \mathrm{mL})$ and Baraldi et al. [20] $(4.3 \mathrm{pg} / \mathrm{mL})$. This could be related to $\mathrm{PM}_{10}$ levels recorded in our city, because it has been reported that PM10 trigger a systemic reaction from lungs to bloodstream in mice [28], and its levels were higher than those considered normal in the Mexican's Official Norm [29]. Also, in the last three years the average levels of PM10, reported by the Air Quality in Europe in cities of similar studies were $28 \mu \mathrm{g} / \mathrm{m}^{3}$ in London, UK and $49.4 \mu \mathrm{g} / \mathrm{m}^{3}$ in Padova, Italy [30]; significantly lower than in our population $\left(196.7 \mu \mathrm{g} / \mathrm{m}^{3}\right)$. So, it supports additional insight into the toxicity of PM10 and could facilitate shedding light on mechanisms underlying the development of urban air pollution related diseases. Other factors that can also explain this difference are genetics, lifestyle, socioeconomic and geographic location. It is unlikely that the variation between Cys-LTs levels may be due to factors related to the sample processing, because it was collected by the same method, and a similar kit was used.

Another factor related to Cys-LTs levels was passive smoking. Supporting this relationship, recently the exposure to environmental tobacco smoke (ETS), as assessed by urinary cotinine levels, was associated with an increased urinary concentration of LTE (4) [31]. Also, it has been reported that ETS modifies the acute effects of low-level ambient $\operatorname{PM}(2.5)$ exposure on childhood asthma. This negative interaction, the smaller effect of particulate matter exposure in children exposed to higher ETS, may be related to a nonlinear dose-response relationship between asthma mediators and particulate exposures [32].

One limitation of the study is that it was a crosssectional study; it would be desirable to measure the levels of Cys-LT at least once in every season to determine their variability and association with levels of pollutants and respiratory health damage. Also, in future studies, independent biomarkers of airway inflammation and/or oxidative stress including exhaled nitric oxide [33] and EBC concentrations of isoprostanes [34,35] and metabolites [36,37] should be measured for a more complete assessment of airway inflammation in children exposed to high PM10 levels. Analysis of breath volatile organic compound profiles with electronic noses [38] would be particularly interesting as this technique has been shown to be reproducible and reliable [39], as well as another new specific non-invasive technique for assessing airway inflammation such as nuclear magnetic resonance-based metabolomics of EBC [37]. Also, pharmacological studies aimed at measuring EBC CysLTs after treatment with leukotriene receptor antagonists in asthmatic children exposed to high PM10 levels or passive smoking are required [40].

However, strength in our study is that we performed a re-power calculation using the difference in standard deviations and means in addition to only $10 \%$ difference between groups in Cys-LT levels and the result was $93 \%$.

\section{Conclusions}

Cys-LTs levels are higher in asthmatic children than in healthy children in a contaminated city and its levels are also associated with passive smoking.

Competing interests

The authors declare that they have no competing interests. 


\section{Authors' contributions}

BLS carried out the design of the study and the acquisition of data, performed the laboratory analysis, the statistical analysis and interpretation of the data and drafted and revised the manuscript. GCS, NAL and JMGM performed the laboratory analysis, the statistical analysis and interpretation of the data and drafted and revised the manuscript. ENL participated in the acquisition and analysis of data and the laboratory analysis. DRA participated in the acquisition and analysis of the data. XSRG, RMT, participated in the design and coordination of the study and helped to interpret the data and to draft the manuscript. All authors read and approved the final manuscript.

\section{Acknowledgements}

We are indebted to the technicians and teachers, but especially to the children who participated and their parents.

This study was supported by the Public Health Institute of the State of Guanajuato, ISAPEG grants (CS-3O130108).

This article was supported in part by grant titled: Training in Environmental Health to Reduce Chronic Disease in Latin America del Mount Sinai School of Medicine (D43 ES 018745) funded by the National Institute of Environmental Health Sciences, Dr. Luz Claudio, Principal Investigator.

\section{Author details}

'Department of Medicine and Nutrition, Division of Health Sciences, University of Guanajuato, León, Guanajuato, México. ${ }^{2}$ Department of Teaching and Research PEMEX Regional Hospital Salamanca, Salamanca, Guanajuato, México. ${ }^{3}$ UMAE HE 1, Instituto Mexicano del Seguro Social, Leon, Guanajuato, México. ${ }^{4}$ Universidad De La Salle Bajío, León, Guanajuato, México. ${ }^{5}$ Department of Pharmacy, Division of Natural Sciences, University of Guanajuato, Guanajuato, México. ${ }^{6}$ Department of Medicine and Nutrition, University of Guanajuato, 20 de Enero \#929, Col. Obregón, León, Guanajuato Z.C. 37320 , México.

Received: 16 January 2014 Accepted: 3 July 2014

Published: 8 July 2014

\section{References}

1. World Health Organization: Guidelines for air quality. Geneva: WHO; 1999.

2. Schildcrout J, Sheppard L, Lumley T, Slaughter J, Koenig J, Shapiro G: Ambient air pollution and asthma exacerbations in children: an eightcity analysis. Am J Epidemiol 2006, 164:505-517.

3. Witten A, Solomon G, Abbritti E, Arjomandi M, Zhai W, Kleinman M, Balmes J: Effects of nitrogen dioxide on allergic airway responses in subjects with asthma. JOEM 2005, 47:1250-1259.

4. Barraza-Villareal A, Sanín-Aguirre L, Tellez-Rojo M, Lacasaña-Navarro M, Romieu l: Prevalencia de asma y otras enfermedades alérgicas en niños escolares de Ciudad Juárez, Chihuahua. Salud Publica Mex 2001, 43:433-443.

5. Ramírez-Sánchez H, Andráde-García M, Gonzáles-Castañeda M, Celis-de la Rosa A: Contaminantes atmósféricos y su correlación con infecciones agudas de las vías respiratorias en niños de Guadalajara, Jalisco. Salud Publica Mex 2006, 48:385-394.

6. Linares B, Guizar JM, Amador N, Garcia A, Miranda V, Perez JR, Chapela R: Impact of air pollution on pulmonary function and respiratory symptoms in children. Longitudinal repeated-measures study. BMC Pulm Med 2010, 10:62.

7. D'Amato G, Holgate ST (Eds): The Impact of Air Pollution on Respiratory Health. Monograph of the European Respiratory Society (no. 21). Sheffield: European Respiratory Society; 2002.

8. Karr C, Lumley T, Schreuder A, Davis R, Larson T, Ritz B, Kaufman J: Effects of subchronic and chronic exposure to ambient air pollutants on infant bronchiolitis. Am J Epidemiol 2007, 165:553-560.

9. Ferrís J, Ortega J, López J, García J, Aliaga J, Cánovas A, Ferris V: Autobuses escolares y motores diesel: contaminación atmosférica, exposición pediátrica y efectos adversos en la salud humana. Rev Esp Pediatr 2003, 59:132-145.

10. Blic J, Tillie-Leblond I: Difficult asthma in children: An analysis of airway inflammation. J Allergy Clin Immunol 2004, 113:94-100.

11. Hazucha M, Bates D, Bromberg P: Mechamism of action of ozone on the human lung. J Appl Physiol 1989, 67:1535-1541.

12. Pryor W: Can vitamin E protect human against the pathological effects of ozone in smog? Am J Clin Nutr 1991, 53:702-722.
13. Devlin R, McDonnell W, Becker S, Madden M, McGee M, Perez R, Hatch $\mathrm{G}$, House D, Koren H: Time-dependet changes of inflammatory mediators in the lungs of human exposed to $0.4 \mathrm{ppm}$ ozone for $2 \mathrm{hr}$ : a comparison of mediators found in bronchoalveolar lavage fluir 1 and $18 \mathrm{hr}$ after exposure. Toxicol Appl Pharmacol 1996, 138:176-185.

14. Koren H, Devlin R, Becker S, Perez R, McDonnell W: Time-dependent Changes of markers associated with inflammation in the lungs of humans eposed to ambient levels of ozone. Toxicol Pathol 1991, 19:406-411.

15. Carraro S, Corradi M, Zanconato S, Alinovi R, Pasquale M, Zacchello F: Exhaled breath condensate Cysteinil leukotrienes are increased in children with exercise-induced bronchoconstriction. J Allergy Clin Immunol 2005, 115:764-770.

16. Lex C, Zacharasiewicz A, Payne D, Wilson N, Nicholson A, Kharitonov S, Barnes $P$, Bush A: Exhaled breath condensate cysteinyl leukotrienes and airway remodeling in childhood asthma: a pilot study. Respir Res London U K 2006, 7:1-7.

17. Instituto Nacional de Ecología (INE): Cuarto almanaque de datos y tendencias de la calidad del aire en 20 ciudades mexicanas (2000-2009). México: SEMARNAT; 2011.

18. Hankinson JL, Odencrantz JR, Fedan KB: Spirometric reference values from a sample of the general US population. Am J Respir Crit Care Med 1999, 159:179-187.

19. Csoma Z, Kharitonov S, Balint B, Bush A, Wilson N, Barnes P: Increased Leukotrienes in Exhaled Breath Condensate in Childhood Asthma. Am J Respir Crit Care Med 2002, 166:1345-1349.

20. Baraldi E, Carraro S, Alinovi R, Pesci A, Ghiro L, Bodini A, Piacentini G, Zacchello F, Zanconato S: Cysteinil leukotrienes and 8-isoprostane in exhaled breath condensate of children with asthma exacerbations. Am J Respir Crit Care Med 2003, 58:505-509.

21. Holgate ST, Peters-Golden M, Panettieri RA, Henderson WR Jr: Roles of cysteinyl leukotrienes in airway inflammation, smooth muscle function, and remodeling. J Allergy Clin Immunol 2003, 111:S18-S34.

22. Montuschi P: Leukotrienes, antileukotrienes and asthma. Mini Rev Med Chem 2008, 8:647-656.

23. Panettieri RA, Tan EM, Ciocca V, Luttmann MA, Leonard TB, Hay DW: Effects of LTD4 on human airway smooth muscle cell proliferation, matrix expression, and contraction In vitro: differential sensitivity to cysteinyl leukotriene receptor antagonists. Am J Respir Cell Mol Biol 1998, 19:453-461.

24. Medina L, Perez-Ramos J, Ramirez R, Selman M, Pardo A: Leukotriene C4 upregulates collagenase expression and synthesis in human lung fibroblasts. Biochim Biophys Acta 1994, 1224:168-174.

25. Salmon M, Walsh DA, Koto H, Barnes PJ, Chung KF: Repeated allergen exposure of sensitized Brown-Norway rats induces airway cell DNA synthesis and remodelling. Eur Respir J 1999, 14:633-641.

26. Montuschi P, Barnes PJ: New perspectives in pharmacological treatment of mild persistent asthma. Drug Discov Today 2011, 16:1084-1091.

27. Mondino C, Ciabattoni G, Koch P, Pistelli R, Trové A, Barnes PJ, Montuschi P: Effects of inhaled corticosteroids on exhaled leukotrienes and prostanoids in asthmatic children. J Allergy Clin Immunol 2004, 114:761-767.

28. Farina F, Sancini G, Battaglia C, Tinaglia V, Mantecca P, Camatini M, Palestini P: Milano summer particulate matter (PM10) triggers lung inflammation and extra pulmonary adverse events in mice. PLoS One 2013, 8:e56636.

29. Norma Oficial Mexicana 025-SSA1-1993. Salud ambiental. Criterio para evaluar la calidad del aire ambiente, con respecto a las partículas menores de 10 micras (PM10): Environmental Health. Criteria for assessing ambient air quality with respect to particles smaller than 10 microns. http://www.salud.gob.mx/unidades/cdi/nom/025ssa13.html, downloaded on January 11, 2014.

30. Air Quality in Europe. http://www.airqualitynow.eu/es/ comparing_year_average.php, downloaded on May 20, 2014.

31. Hernández-Alvídrez E, Alba-Reyes G, Muñoz-Cedillo BC, Arreola-Ramírez JL, Furuya ME, Becerril-Ángeles M, Vargas MH: Passive smoking induces leukotriene production in children: influence of asthma. J Asthma 2013, 50:347-353.

32. Rabinovitch N, Silveira L, Gelfand EW, Strand M: The response of children with asthma to ambient particulate is modified by tobacco smoke exposure. Am J Respir Crit Care Med 2011, 184:1350-1357. 
33. Montuschi P, Mondino C, Koch P, Ciabattoni G, Barnes PJ, Baviera G: Effects of montelukast treatment and withdrawal on fractional exhaled nitric oxide and lung function in children with asthma. Chest 2007, 132:1876-1881.

34. Barreto M, Villa MP, Olita C, Martella S, Ciabattoni G, Montuschi P: 8Isoprostane in exhaled breath condensate and exercise-induced bronchoconstriction in asthmatic children and adolescents. Chest 2009, 135:66-73.

35. Montuschi P, Barnes PJ, Ciabattoni G: Measurement of 8-isoprostane in exhaled breath condensate. Methods Mol Biol 2010, 594:73-84

36. Montuschi P, Paris D, Melck D, Lucidi V, Ciabattoni G, Raia V, Calabrese C, Bush A, Barnes PJ, Motta A: NMR spectroscopy metabolomic profiling of exhaled breath condensate in patients with stable and unstable cystic fibrosis. Thorax 2012, 67:222-228.

37. Motta A, Paris D, Melck D, de Laurentiis G, Maniscalco M, Sofia M, Montusch $P$ : Nuclear magnetic resonance-based metabolomics of exhaled breath condensate: methodological aspects. Eur Respir J 2012, 39:498-500

38. Montuschi P, Mores N, Trové A, Mondino C, Barnes PJ: The electronic nose in respiratory medicine. Respiration 2013, 85:72-84.

39. Bofan M, Mores N, Baron M, Dabrowska M, Valente S, Schmid M, Trové A, Conforto S, Zini G, Cattani P, Fuso L, Mautone A, Mondico C, Pagliari G, D'Alessio T, Montuschi P: Within-day and between-day repeatability of measurements with an electronic nose in patients with COPD. J Breath Res 2013, 7:017103.

40. Montuschi P, Peters-Golden ML: Leukotriene modifiers for asthma treatment. Clin Exp Allergy 2010, 40:1732-1741.

\section{Submit your next manuscript to BioMed Central and take full advantage of:}

- Convenient online submission

- Thorough peer review

- No space constraints or color figure charges

- Immediate publication on acceptance

- Inclusion in PubMed, CAS, Scopus and Google Scholar

- Research which is freely available for redistribution

Submit your manuscript at www.biomedcentral.com/submit
C Biomed Central 